Review

\title{
The Role of the Immune Response in Merkel Cell Carcinoma
}

\author{
Pierre L. Triozzi ${ }^{1, *}$ and Anthony P. Fernandez ${ }^{2}$
}

1 Taussig Cancer Institute, Cleveland Clinic Foundation, 9500 Euclid Avenue, Cleveland, OH 44195, USA

2 Departments of Dermatology and Anatomic Pathology, Cleveland Clinic Foundation, 9500 Euclid Avenue, Cleveland, OH 44195, USA; E-Mail: fernana6@ccf.org

* Author to whom correspondence should be addressed; E-Mail: triozzp@ccf.org; Tel.: +1-216-445-5141; Fax: +1-216-636-2498.

Received: 7 December 2012; in revised form: 30 January 2013 / Accepted: 6 February 2013 / Published: 28 February 2013

\begin{abstract}
Merkel cell carcinoma (MCC) is an aggressive neuroendocrine skin cancer. The Merkel cell polyomavirus (MCPyV) is implicated in its pathogenesis. Immune mechanisms are also implicated. Patients who are immunosuppressed have an increased risk. There is evidence that high intratumoral T-cell counts and immune transcripts are associated with favorable survival. Spontaneous regressions implicate immune effector mechanisms. Immunogenicity is also supported by observation of autoimmune paraneoplastic syndromes. Case reports suggest that immune modulation, including reduction of immune suppression, can result in tumor regression. The relationships between $\mathrm{MCPyV}$ infection, the immune response, and clinical outcome, however, remain poorly understood. Circulating antibodies against MCPyV antigens are present in most individuals. MCPyV-reactive $\mathrm{T}$ cells have been detected in both MCC patients and control subjects. High intratumoral T-cell counts are also associated with favorable survival in MCPyV-negative MCC. That the immune system plays a central role in preventing and controlling MCC is supported by several observations. MCCs often develop, however, despite the presence of humoral and cellular immune responses. A better understanding on how MCPyV and MCC evade the immune response will be necessary to develop effective immunotherapies.
\end{abstract}

Keywords: merkel cell polyomavirus; immune suppression; tumor infiltrating lymphocytes; regulatory $\mathrm{T}$ cells; immunotherapy 


\section{Introduction}

Merkel cell carcinoma (MCC) is a rare, neuroendocrine carcinoma that originates in the skin from cells that normally function as mechanoreceptors. It is an aggressive neoplasm that has a predilection for local recurrence, regional metastasis to lymph nodes, and distant metastasis to lung, liver, bone, and brain. MCC arises primarily on sun-exposed areas, with the head and neck being most commonly affected. Older, lighter-skinned individuals with a history of significant sun exposure are at the highest risk [1]. Approximately $80 \%$ of MCCs harbor the Merkel cell polyomavirus (MCPyV), a small, non-enveloped, double-stranded DNA virus that appears to play a role in its molecular pathogenesis [2]. As with most cutaneous malignancies, surgery is the mainstay of therapy. Although definitive evidence is lacking, there are data suggesting that radiation to the primary site and involved regional lymph nodes can improve locoregional control [3]. There is, however, little evidence that radiation affects overall survival. The chemotherapeutics usually administered are those used to treat small-cell lung carcinoma, also a high-grade neuroendocrine carcinoma. Whether chemotherapy in the setting of metastatic disease improves survival is not established [4,5]. Furthermore, the retrospective analyses that have been conducted do not indicate that adjuvant chemotherapy improves overall survival $[6,7]$.

Although named after the cancer in which it was discovered, MCPyV is prevalent in normal skin, being detected in over $90 \%$ of forehead swabs from patients with MCC and in 60 to $80 \%$ of skin swabs from healthy volunteers [8,9]. Similar to other polyomaviruses, MCPyV encodes two major families of genes, early and late. The early genes encode the $\mathrm{T}$ antigens, proteins that promote replication of viral DNA. The largest of the T antigens (LT-Ag) is persistently expressed in a truncated form in MCC tumors and likely promotes cell division by inhibiting the retinoblastoma tumor suppressor protein. At the same time, the truncated LT-Ag no longer induces lytic viral replication that would be lethal to a cancer cell. The small $\mathrm{T}$ antigen (ST-Ag), which shares the first 78 amino acids with LT-Ag, is also expressed in MCC tumors. It is thought to inhibit the tumor suppressor protein phosphatase $2 \mathrm{~A}$ through its unique c-terminal domain [10,11]. The late genes encode proteins that form the viral capsid. Although required for initial infection, capsid expression cannot be detected in MCC tumors and, thus, does not appear to play a role in tumor persistence [12]. Individuals with MCPyV-positive MCC may have more favorable outcome than those with MCPyV-negative MCC. Mutations in the TP53 tumor suppressor gene, which are associated with a poor prognosis and resistance to therapy of many cancers, are more frequent in MCPyV-negative MCCs [13].

That tumor immune surveillance exists in humans is supported by a number of clinical observations, including the increased risk of tumor development in immunosuppressed patients, instances of spontaneous tumor regression, and appearance of tumor-reactive antibodies and $\mathrm{T}$ cells. Several clinical observations implicate the immune response in the development and progression of MCC. Herein we review the role of the immune response on the incidence and course of MCC, including the role of MCPyV-specific immune responses. The potential for immune modulating therapies is also reviewed. 


\section{Incidence}

Immunosuppression caused by either therapy or by primary or secondary immunodeficiencies is associated with an increased risk of many malignancies. Although over $90 \%$ of MCC patients do not have any overt immune dysfunction, the association between MCC and immunosuppression is well established. It has been estimated that the risk of MCC increases 15-fold over the general population in immunosuppressed patients [14]. In organ transplant patients receiving immunosuppressives, skin cancers are the most common cancers that develop. Although MCC accounts for less than 5\% of all skin cancers in organ transplant recipients, these patients have a relative risk for the development of MCC estimated to be approximately 10-fold higher than the general population [15]. It was noted in a review of 41 cases of MCC reported to the Cincinnati Transplant Tumor Registry (now called the Israel Penn International Transplant Tumor Registry) that patients with MCC in the setting of organ transplantation tended to be younger [16]. The mean age at diagnosis was 53 (range 33-78) years, and $29 \%$ of recipients were less than 50 years old. The tumor appeared from approximately 6 months to 24 years after the transplant with the mean being approximately 8 years. The site of development was similar to that seen in the non-transplant population, with the head and neck being the most commonly affected. Approximately half of the transplant recipients with MCC had other malignancies, the great majority of which (91\%) were other skin cancers. That $68 \%$ of patients in this case series developed lymph node metastases and 56\% died of their malignancies supported the possibility that MCC in the transplant setting was more aggressive that in the general population. Review of the Finnish Cancer Registry also suggested that patients with MCC in the organ transplant setting are younger and manifest aggressive clinical courses [17]. An association with autoimmune disease was also raised. Only one of the three MCC cases reported in this series was MCPyV positive.

A 30-fold increased incidence of MCC in patients with chronic lymphatic leukemia (CLL) has been reported; an increased incidence has also been observed in patients with multiple myeloma and non-Hodgkin lymphoma (NHL) [18]. Cell-mediated immune responses are compromised in the setting of lymphoid malignancies, and these patients may have a higher propensity for colonization with MCPyV, thus influencing the subsequent development of MCC. Patients with lymphoid malignancies also often receive T-cell-suppressive therapies that may influence infection with and behavior of MCPyV and ultimately the course of MCC. Review of cases in the Surveillance, Epidemiology, and End Results program found that overall survival among patients with MCC with a history of CLL or NHL was worse than expected [19]. MCC cause-specific survival was also worse than expected for patients with a history of CLL, but no difference was observed for NHL. Whether MCC predisposes to hematologic malignancy is not known. Epidemiological data, however, do indicate an increase in hematological malignancies, primarily lymphoid, diagnosed after diagnosis of MCC [18]. Interestingly, $\mathrm{MCPyV}$ is only rarely detected in tissue from these hematologic malignancies, and then only at low viral loads [20,21]. It may be an immune aberration leads to both malignancies or be merely the result of increased surveillance of these patients. The incidence of MCC is also increased in patients treated for autoimmune disease and in the setting of HIV infection [22,23]. 


\section{Clinical Course}

\subsection{Tumor Infiltrating Cells}

In many solid tumors, including cutaneous melanoma, the presence of tumor infiltrating lymphocytes (TILs) is associated with a better prognosis, supporting a role for the immune response in regulating clinical course [24-26]. Several studies have attempted to determine whether specific histologic features of MCC tumors have prognostic significance. Although results have been variable, along with tumor size, the histologic feature found to be most commonly associated with prognosis has been TILs (Table 1). The characterization of TILs has varied but has, for the most part, paralleled the "absent," "nonbrisk" and "brisk" histologic categories applied in cutaneous melanoma [24]. Immunohistochemical methods identifying specific $\mathrm{T}$ cell subsets have also been applied (Figure 1). In studies reported by Andea et al. and Llombart et al., TILs were associated with improved survivals in univariate but not multivariate analyses $[27,28]$. Sitho et al. reported that a high number of CD3 ${ }^{+}$TILs was associated with better survival in a multivariate analysis [29]. Paulson et al. determined that TILs were not an independent prognostic factor when assessed by standard histology, whereas intratumoral, but not peritumoral, $\mathrm{CD} 8^{+}$lymphocyte infiltration was, both univariate and multivariate analyses [30]. The observation that intratumoral and not peritumoral lymphocytes are relevant for outcome has also been reported for other cancers, such as ovarian and colon (Figure 2) [31,32]. In contrast, Mott et al. found an association between heavy lymphocytic infiltration of MCC and a poor outcome [33].

Table 1. Studies of TILs in MCC.

\begin{tabular}{|c|c|c|c|c|}
\hline Study & $\mathbf{N}$ & TIL Characterization & Survival & Comment \\
\hline $\begin{array}{l}\text { Mott et al. } \\
2004 \text { [33]. }\end{array}$ & 25 & $\begin{array}{l}\text { Minimal } / \text { moderate }=17 \\
(68 \%) \\
\text { Heavy }=8(32 \%)\end{array}$ & $\begin{array}{l}\text { "Heavy" infiltration was } \\
\text { associated with poor } \\
\text { prognosis in multivariate } \\
\text { analysis. }\end{array}$ & $\begin{array}{l}\text { Depth of invasion was associated } \\
\text { with poor prognosis in multivariate } \\
\text { analysis. }\end{array}$ \\
\hline $\begin{array}{l}\text { Llombart } \\
\text { et al. } 2005 \\
{[28] .}\end{array}$ & 20 & $\begin{array}{l}\text { Absent }=8(40 \%) \\
\text { Discontinuous }=12 \\
(60 \%) \\
\text { Continuous }=0\end{array}$ & $\begin{array}{l}\text { "Absent" was an } \\
\text { independent prognostic } \\
\text { factor of DFI in } \\
\text { multivariate analysis. }\end{array}$ & $\begin{array}{l}\text { Tumor size }>30 \mathrm{~mm} \text {, stage II, and } \\
\text { the presence of }>50 \% \text { of Ki } 67+ \\
\text { tumor cells were found to be } \\
\text { prognostic indicators of disease } \\
\text { free interval in univariate analysis. }\end{array}$ \\
\hline $\begin{array}{l}\text { Andea et al. } \\
2008 \text { [27]. }\end{array}$ & 156 & $\begin{array}{l}\text { Absent }=81(53 \%) \\
\text { Present nondense }=55 \\
(36 \%) \\
\text { Dense }=17(11 \%)\end{array}$ & $\begin{array}{l}\text { "Present nondense" plus } \\
\text { "Dense" was associated } \\
\text { with longer survival in } \\
\text { univariate analysis. }\end{array}$ & $\begin{array}{l}\text { Nodular growth pattern, low tumor } \\
\text { depth, and absence of } \\
\text { lymphovascular invasion were } \\
\text { associated with longer survival on } \\
\text { multivariate analysis. }\end{array}$ \\
\hline $\begin{array}{l}\text { Paulson } \\
\text { et al. } 2011 \\
{[30] .}\end{array}$ & 130 & $\begin{array}{l}\text { Not identified }=44 \\
(34 \%) \\
\text { Non-brisk/Brisk }=86 \\
(66 \%) \\
\text { CD8+ infiltrates (IHC) } \\
\text { scored on a } 0 \text { to } 5 \text { scale }\end{array}$ & $\begin{array}{l}\text { TILs were associates with } \\
\text { better prognosis on } \\
\text { univariate but not } \\
\text { multivariate analyses. }\end{array}$ & $\begin{array}{l}\text { Intratumoral CD } 8+\text { was } \\
\text { independently associated with } \\
\text { improved survival in multivariate } \\
\text { analysis. }\end{array}$ \\
\hline $\begin{array}{l}\text { Sihto et al. } \\
2012 \text { [29]. }\end{array}$ & 116 & $\begin{array}{l}\text { Numbers of intratumoral } \\
\mathrm{CD}^{+}, \mathrm{CD} 8^{+}, \mathrm{CD} 16^{+}, \\
\mathrm{FoxP}^{+}, \text {and } \mathrm{CD} 68^{+} \\
\text {cells (IHC) per } 1 \text { high } \\
\text { power field }\end{array}$ & $\begin{array}{l}\text { High } \mathrm{CD}^{+}, \mathrm{CD}^{+}, \text {or } \\
\text { FoxP3 }^{+} \text {cells, and high } \\
\mathrm{CD}^{+} / \mathrm{CD}^{+} \text {or } \\
\text { FoxP3 } 3^{+} / \mathrm{CD}^{+} \text {ratios, were } \\
\text { significantly associated } \\
\text { with favorable overall } \\
\text { survival. }\end{array}$ & $\begin{array}{l}\text { Although the numbers of T cells } \\
\text { are generally higher in MCPyV- } \\
\text { positive than in MCPyV-negative } \\
\text { MCC, high intratumoral T-cell } \\
\text { counts are also associated with } \\
\text { favorable survival in MCPyV- } \\
\text { negative MCC. }\end{array}$ \\
\hline
\end{tabular}


Figure 1. Photomicrogaphs (10× magnification) of a cutaneous Merkel cell carcinoma that is fragmented $(\mathrm{H} \& \mathrm{E})$ and associated with an inflammatory infiltrate. Immunohistochemical stains reveal presence of tumor infiltrating lymphocytes (CD3, CD8) and tumor infiltrating macrophages (CD163).
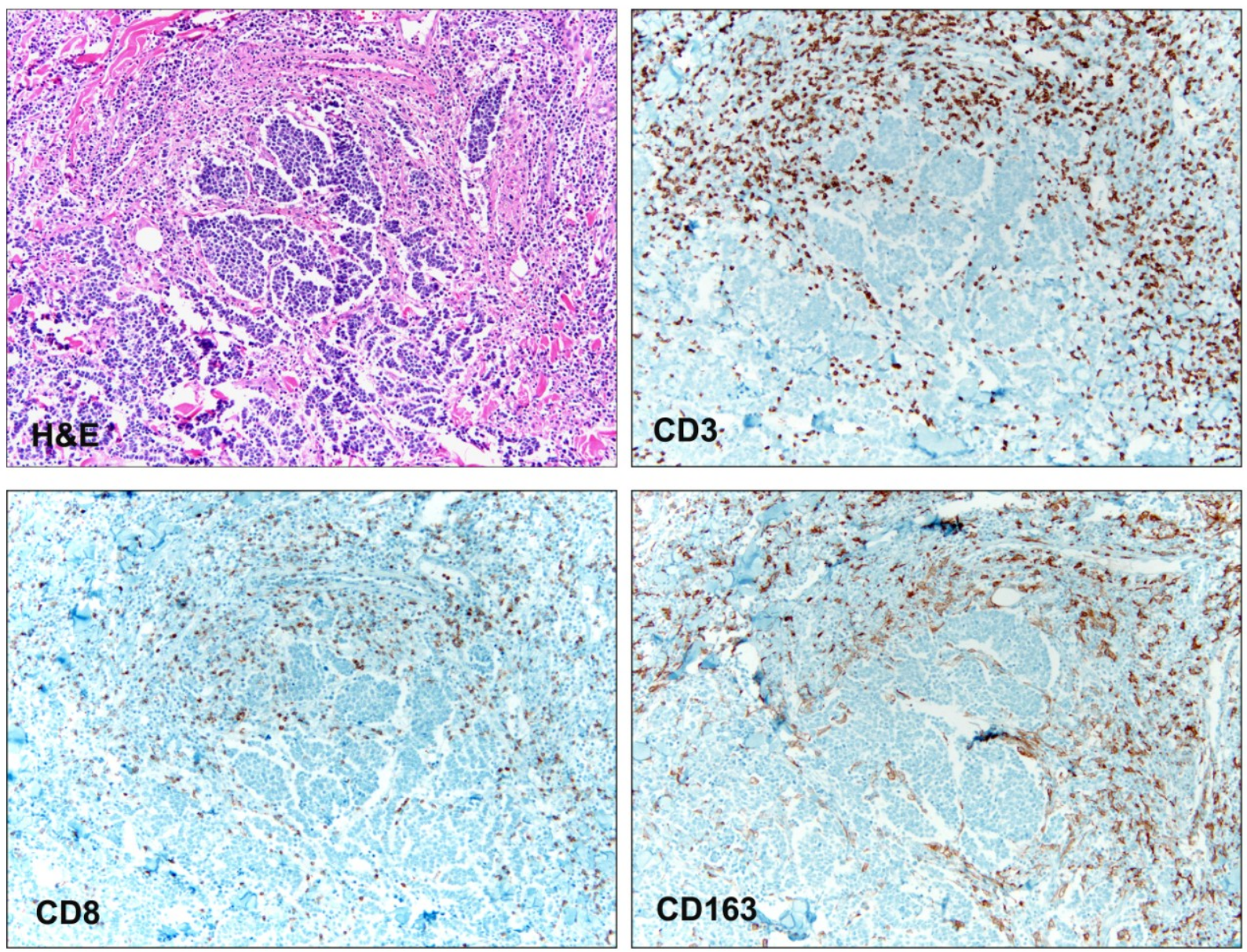

Figure 2. Photomicrographs ( $4 \times$ magnification) of a cutaneous Merkel cell carcinoma displaying sheets of malignant cells (H\&E) throughout the dermis. CD3 and CD8 immunostains highlight T-cells within the papillary dermis, but outside of the tumor. No intratumoral lymphocytes are present.

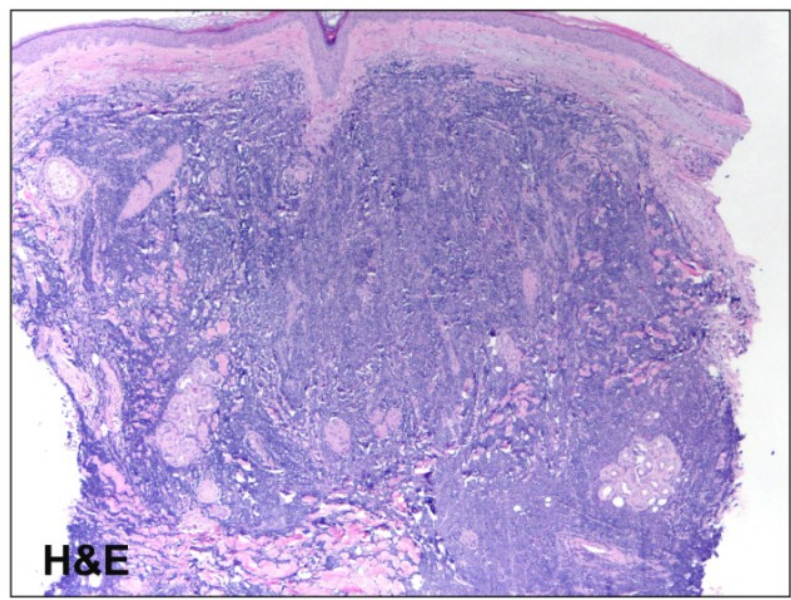


Figure 2. Cont.
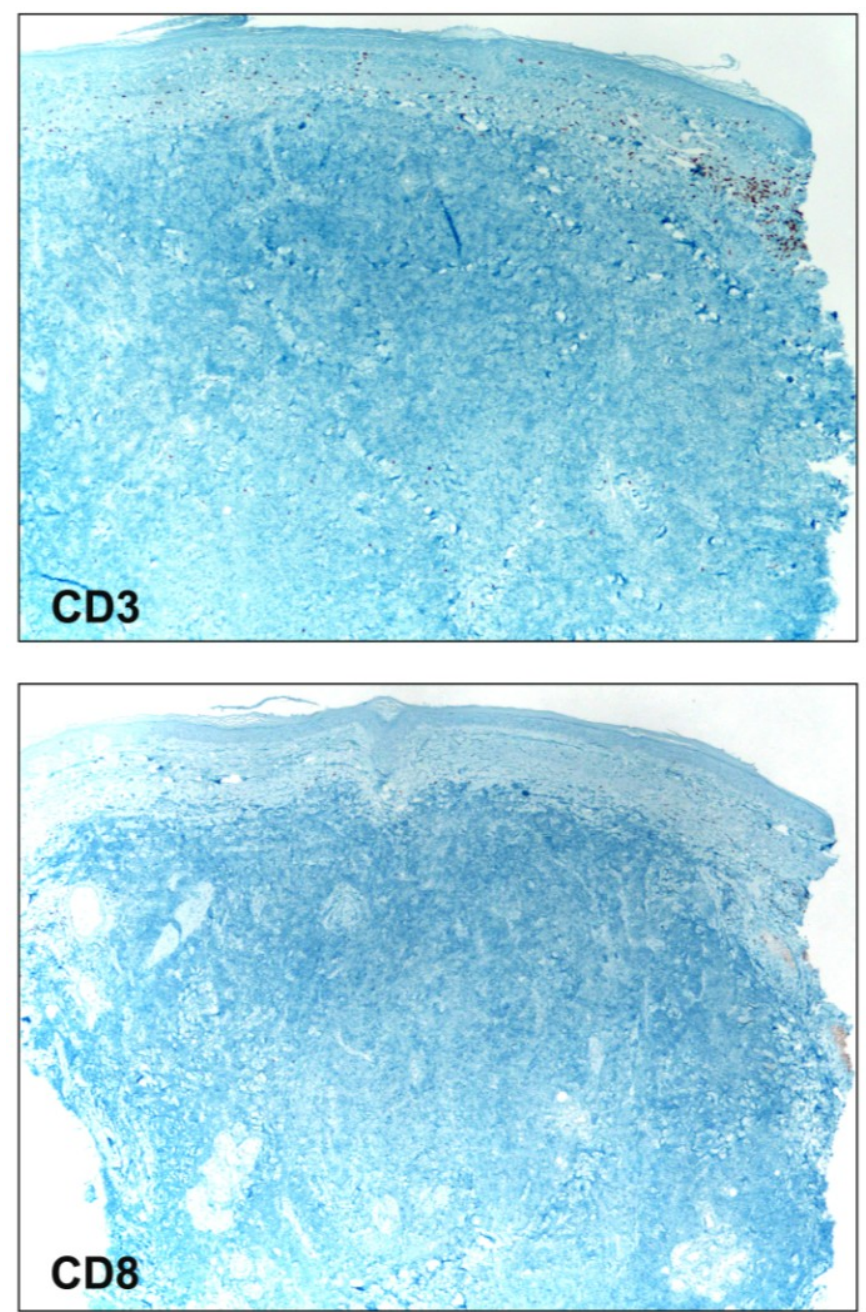

The relationship of TILs in MCC to MCPyV infection is not well established. Sihto et al. found that high numbers of several types of TILs, including $\mathrm{T}$ cells $\left(\mathrm{CD} 3^{+}\right)$, cytotoxic $\mathrm{T}$ cells $\left(\mathrm{CD} 8^{+}\right)$, helper $\mathrm{T}$ cells $\left(\mathrm{CD}^{+}\right)$, regulatory $\mathrm{T}$ (Treg) cells $\left(\mathrm{FoxP}^{+}\right)$, and natural killer $(\mathrm{NK})$ cells (small CD16 ${ }^{+}$cells) were linked with presence of MCPyV DNA. There was, however, no evidence that TILs were restricted to the subset of patients whose tumor harbored MCPyV DNA. Patients whose tumor contained a high number of tumor-infiltrating $\mathrm{T}$ cells had favorable survival, even when the tumor did not harbor MCPyV DNA, and both high intratumoral T-cell count and presence of MCPyV DNA were independent prognostic factors in a multivariate analysis. These results suggested that MCPyV infection enhances TIL infiltration, but other factors also maintain the host antitumor response. Furthermore, they suggested that a favorable prognosis of MCCs with TILs is not explained by the presence of MCPyV alone [29].

That a high tumor FoxP3 ${ }^{+}$Treg cell count was associated with favorable outcome in the studies of Sitho et al. is of interest, since Treg cells are generally implicated in the suppression and not the promotion of antitumor immunity [29]. In fact, patient survival has been shown to correlate negatively with tumor FoxP3 ${ }^{+}$Treg cell infiltration in small-cell lung cancer [34]. Studies in other types of human cancer have been mixed, however, linking high $\mathrm{FoxP}^{+}$cell counts with either favorable or unfavorable survival, and a recent meta-analysis found no association between tumor Treg cell 
infiltration and survival [35]. Tumor infiltrating macrophages, which have been associated with the suppression of antitumor immunity and a poor outcome in several cancers, including cutaneous melanoma [36], have also been identified in MCC tumors (Figure 1). Like TILs, the infiltration of macrophages into MCC tumors has been associated with MCPyV; $\mathrm{CD}^{+} 8^{+}$and $\mathrm{CD}_{163}{ }^{+}$tumor infiltrating macrophages, however, were not significantly associated with survival [29]. Myeloid-derived suppressor cells, a heterogeneous collection of immature myeloid cells with immune suppressive function, have been implicated in promoting the progression of several cancers [37]. Whether these cells are operational in MCC has not been reported.

\subsection{Tumor Immune Transcripts}

Although limited by the heterogeneity of the tissues examined, several groups have applied molecular profiling techniques to examine intratumoral immune responses [38]. Paulson et al. examined gene expression profiles in MCC tumors and found those of patients considered to have a favorable prognosis, namely an absence of nodal disease at presentation and an absence of progression at 24 months, were enriched for immune response genes, especially those expressed by $\mathrm{CD} 8^{+}$ lymphocytes [30]. Prominently represented were genes encoding components of cytotoxic granules (granzymes A, B, H, and K), chemokines (CCL19), lymphocyte activation genes (SLAMF1 and $N K G 2 D)$, and $\alpha$ chain of the CD8 receptor $(C D 8 a)$. No association was found between these and tumor MCPyV status. Intratumoral cytokine transcripts were also reported by Arany et al. [39]. There was a lack of cytokine transcripts, such as $I L 2$ and $I F N G$, typical for a specific, T cell-mediated immune response. However, several cytokine transcripts were produced, such as $I L 12$, that are required for the activation of this response. Epithelial genes associated with proliferation, such as c-myc, cdc 2 kinase, $E 2 F$, proliferating cell nuclear antigen, $T P 53, R B, \mathrm{CK} 5$, and CK10, were also highly expressed.

\subsection{Spontaneous Regression}

Although the mechanism for this phenomenon is uncertain, that the immune response influences progression of MCC is also supported by observations of spontaneous regression. It is difficult to determine the incidence of spontaneous regression of any cancer, primarily because treatment is usually initiated soon after diagnosis. Based on reviewing published reports, which are limited by reporting biases, the estimated rate of regression in MCC is $1.4 \%$, which is very low [40]. Approximately $10 \%$ of patients diagnosed with MCC, primarily elderly men, will present with an unknown primary $[41,42]$. There are data that patients with an occult primary tumor may have better disease-free and overall survivals compared to those without an occult primary tumor, suggesting that resolution of the primary tumor may be an immune-mediated phenomenon that persists when the tumor arises elsewhere $[43,44]$. Spontaneous regression of an established MCC has only rarely been reported, less than 20 cases, about half of which were metastatic lesions [45]. It appears to be more common in women, in nodal site, when the primary site is the head or neck, and after biopsy or fine needle aspiration. The "abscopal" regression of untreated lesions in a patient undergoing radiation, also considered to be an immune mediated phenomenon, has also been reported [46]. Of note, spontaneous regression can be sustained. 
Studies of primary and metastatic MCC that were observed to regress have demonstrated infiltration by immune cells, including $\mathrm{CD}^{+}, \mathrm{CD}^{+}$, and $\mathrm{CD} 3^{+} \mathrm{T}$ cells and macrophages [47-49]. An examination of tumors that subsequently partially or completely regressed after biopsy found a significant increase in $\mathrm{T}$ cells compared to tumors that did not regress [50]. Given that intratumoral infiltration of $\mathrm{CD} 8^{+} \mathrm{T}$ cells was associated with a favorable prognosis, whether diagnostic biopsy induces intratumoral CD $8^{+}$ $\mathrm{T}$ cells in MCC was examined; it did not [51]. Lymph nodes draining areas of spontaneous cutaneous regressions have also been examined. They have been enlarged with extensive fibrosis and accumulation chronic inflammatory cells including many $\mathrm{T}$ cells and macrophage, suggesting a previous immune-mediated response there, perhaps to metastatic foci $[45,48,52,53]$. Spontaneous regression has been observed in other virus-associated tumors [54-56]. That an immune response to the MCPyV may be operational in the regression of MCC has been speculated but not established [57].

\subsection{Paraneoplastic Autoimmune Syndromes}

Several cancers have been associated with paraneoplastic autoimmune syndromes caused by activation of an immune response specific for self antigens expressed on tumor cells. These too support the immunogenicity of tumors; and although their impact is not established, there is evidence that the presence of an autoimmune paraneoplastic syndrome can confer a survival advantage in small-cell lung cancer [58]. As with other cancers of neuroendocrine derivation, paraneoplastic neurologic disorders have been observed in MCC. Antibodies to cerebellar nerve fibers have been reported in a patient with paraneoplastic cerebellar ataxia associated with MCC [59]. Anti-Hu antibodies have been reported in a MCC patient with painless proximal muscle weakness [60] and in a patient with progressive sensorimotor neuropathy, autonomic neuropathy with gastroparesis, and encephalopathy with cognitive decline [61]. Novel antibodies reactive to filamentous structures in brain and cerebellum were found in a patient with MCC and paraneoplastic brainstem encephalitis [62]. Lambert-Eaton myasthenic syndrome has also been associated with MCC [63]. How the presence of a paraneoplastic syndrome affects the clinical course of MCC course is not known.

\subsection{Reduction of Immune Suppression}

The evidence that the reduction or withdrawal of immune suppression plays a role in the treatment of MCC is, for the most part, anecdotal but further support a role for immune surveillance in association with this rare malignancy. There are case reports of MCC regression in response to withdrawal of immune suppressive therapeutics such as azathioprine and cyclosporine [64,65]. Nonetheless, there is a general consensus that reduction or withdrawal of immune suppression in high-risk transplant-associated skin cancers warrant consideration, particularly in situations where the allograft is not lifesaving (e.g., renal). Several studies have shown a lower incidence of malignancies, including solid tumors of all types, when inhibitors mammalian target of rapamycin, which have been shown to have anti-viral properties, are used alone or in combination with standard agents [66]. How specific immune suppressive drugs influence MCC development is not known. 


\section{MCPyV Immune Response}

\subsection{Humoral}

Circulating antibodies against MCPyV viral capsid proteins are present in most patients with MCC and in approximately $50 \%$ of children under 15 and up to $80 \%$ of healthy people over 50 years of age in the general population. Although the prevalence of antibodies to viral capsid proteins in the general population is high, all studies have found that titers of IgG antibodies to MCPyV vial capsid proteins are higher in patients with MCC [12,67-71]. As noted, MCC tumor cells do not express viral capsid proteins, suggesting that the higher titers are not attributable to increased viral capsid antigen production by tumor cells. A positive correlation between antibody titers and viral load has been observed for other viral infections, including other polyomavirus infections [72-76]. MCPyV DNA levels in cutaneous swabs from MCC patients are significantly higher than controls, and a positive correlation between MCPyV capsid antibody titers and MCPyV DNA levels in skin biopsies has been observed $[8,77,78]$. Thus, high antibody titers in MCC patients may be the result of poorly controlled $\mathrm{MCPyV}$ infection and high viral loads, perhaps promoted by an immune deficiency or an aberrant immune response to viral infection.

Compared to antibodies to viral capsid proteins, antibodies to $\mathrm{MCPyV} \mathrm{T}$-antigens are more specifically associated with MCC. T-antigens are not present in viral particles. They are only expressed after viral entry into host cell nuclei, and likely only elicit an antibody response when released by dying infected cells [79]. In approximately $40 \%$ of patients with MCC, serum $\operatorname{IgG}$ antibodies that recognize a portion of T-antigen shared between LT-Ag and ST-Ag can be identified. These antibodies are rarely detected in the general population $(<1 \%)$. Importantly, antibody titers correlate strongly with the presence of MCPyV DNA and the expression of T-antigens in MCC tumors. Moreover, titers decrease after successful treatment, and a rising titer in a previously treated patient has been shown to herald disease progression [71]. Whether following T-antigen titers may be used clinically to determine whether treatment is successful or to detect a recurrence requires further study.

Whether humoral responses modulate clinical course is not known. Although antibodies recognizing $\mathrm{MCPyV}$ capsid and T-antigens are associated with $\mathrm{MCC}$, they obviously do not protect against disease development. Higher anti-MCPyV capsid antibody titers were associated with a better disease-free survival in one study [80]. Whether this indicates the influence of an antitumor immune response remains unclear. It may reflect $\mathrm{MCPyV}$ burden. As noted, patients with MCPyV-negative MCC tumors tend to do less well, perhaps on the basis of altered cellular intrinsic growth mechanisms. The limited serologic data from patients with MCPyV-negative MCC tumors suggest, however, that the majority of these patients have been exposed to MCPyV [70], and in many patients antibody titers can be very high, similar to patients with MCPyV-positive MCC [67]. This suggests the possibility that selection of less immunogenic, more aggressive, MCPyV-negative MCC tumor subclones has occurred in these patients. Antibodies against autologous tumor cell proteins in patients with small-cell lung cancer are associated with improved survival [81]. That antibodies against autologous tumor cell proteins are present in patients with MCC has not been reported. 


\subsection{Cellular}

Although humoral response can contribute antitumor activity, the generation of cellular immunity is considered central to tumor elimination. T-cell responses have been described to occur against other polyomaviruses and to other cancer-associated viruses, such as human papilloma (HPV) and hepatitis $\mathrm{C}$ viruses, albeit infrequently [82-85]. That anti-MCPyV antibodies are IgG implies the presence of MCPyV-specific CD4 ${ }^{+} \mathrm{T}$-cell help. Compared to MCPyV-seronegative, the $\mathrm{CD}^{+} \mathrm{T}$ cells from seropositive volunteers have been shown to respond with significantly higher proliferation and interferon-(IFN-) $\gamma$, IL-10, and IL-13 production when stimulated with MCPyV capsid protein [86]. Iyer et al. reported the presence of MCPyV-reactive $\mathrm{T}$ cells in MCC patients [87]. They isolated virus-reactive $\mathrm{CD} 8^{+}$or $\mathrm{CD}^{+} \mathrm{T}$ cells from $\mathrm{MCPyV}$-positive but not from virus-negative MCC tumors. MCPyV-specific T-cell responses were also detected in the blood of MCC patients (14 of 27) and control subjects ( 5 of 13). These $\mathrm{T}$ cells recognized a broad range of peptides derived from the capsid and T-antigen and mediated MHC class I (HLA-A*2402) restricted lysis of cells expressing the LT-Ag. Whether cellular responses modulate clinical course of MCC is not known. Virus-specific $\mathrm{CD}^{+} \mathrm{T}$ cells were markedly enriched among TILs as compared with blood in one patient, as determined by a HLA-LT-Ag tetramer, implying intact T-cell trafficking into the tumor. Although tetramer-positive $\mathrm{CD}^{+} \mathrm{T}$ cells were detected in the blood, these cells failed to produce IFN- $\gamma$ when challenged ex vivo with LT-Ag peptide, suggesting non-responsiveness. The findings to date, however, do suggest that MCC tumors often develop despite the presence of $\mathrm{T}$ cells specific for MCPyV T-antigens. Little is known about the role of the NK cells in the immune defense against MCPyV, but NK cells and also $\gamma \delta \mathrm{T}$ cells have a protective role against polyomavirus-induced tumors in some mouse models [88].

\section{Immunotherapy}

\subsection{Cytokines}

Several cytokines have been effectively applied in cancer therapy. Because of their immunomodulatory, antiviral, and antiproliferative effects, interferons have been used to treat many malignancies. IFN- $\alpha$ is used in the adjuvant setting to treat patients with resected, high-risk cutaneous melanoma. It is also used to treat hepatitis B and C. The antiviral activity of IFN- $\alpha$ and IFN- $\beta$, both type I IFNs, has been demonstrated against polyomaviruses [89,90]. Type I IFNs have also been shown to inhibit MCC cell lines in vitro; type II IFN- $\gamma$ is far less effective [91,92]. The inhibitory effect of type I IFNs on MCPyV-positive MCC cell lines in vitro was associated with a reduced expression of the LT-Ag as well as an increased expression of promyelocytic leukemia protein, which is known to interfere with the function of the LT-Ag. In addition, the intra-lesional application of IFN- $\alpha$ resulted in a regression of MCPyV-positive but not negative MCCs in vivo in a mouse xenograft model [92].

The systemic administration of type I IFNs has been reported to have antitumor activity in patients with MCC. There are case reports of tumor regression with IFN-alfa-2a at 3 million International Units (MIU) subcutaneously three times a week [93] and with IFN- $\beta$ subcutaneously at 3 MIU per day [94]. Two patients treated in another study with recombinant IFN-alfa-2a at a daily dose of 6 MIU intramuscularly for 8 weeks, and 3 times weekly thereafter did not respond [95]. Two patients treated 
with recombinant IFN-alfa-2b at 3 MIU daily in another study also did not respond [96]. Whether dosing of the IFNs was optimal in the patients - 3 MIU is considered to be a low dose - that did not respond was not clear, particularly in light of the biological heterogeneity of MCC outlined above. IFN has also been injected intra-lesionally in a patient [97]. How the presence of MCPyV influences responses is not known.

There are case reports of the potential antitumor activity of other immune regulatory cytokines in MCC. Two patients were treated with intra-lesional injection of natural human tumor necrosis factor (TNF) [98]. Complete tumor responses were achieved in both without causing ulceration or scarring. Three patients with MCC responded to treatment with hyperthermic isolated limb perfusion with TNF- $\alpha$, IFN- $\gamma$, and melphalan [99]. Sustained regression of metastatic MCC with treatment of HIV infection in patient treated with subcutaneous interleukin-(IL-)2 in conjunction with antiretrovirals (stavudine, lamivudine, and ritonavir) [100]. Patients with local and distant MCC will be enrolled in a Phase II clinical trial designed to assess the clinical and biologic effects of increased local expression of IL-12 protein in the MCC tumor microenvironment following treatment with OMS ElectroImmunotherapy [101].

\subsection{Adoptive Cellular}

One method of dealing with immune cell deficiencies in patients with cancer is to infuse immune cells generated ex vivo. A variety of immune effector cells have been generated for adoptive cellular therapy and tested in clinical trials. A recent case report has described the use autologous polyclonal antigen-specific $\mathrm{CD}^{+} \mathrm{T}$ cells targeting the HLA A*2402-restricted epitope of the MCPyV T-Ag oncoprotein in a patient with MCC. Ex-vivo cultures were supplemented with IL-21, which promotes cytolytic T lymphocyte survival. To induce tumor MHC class I up-regulation, IFN- $\beta$ was injected intra-lesionally in one of three lesions prior to the first infusion of polyclonal MCPyV-specific T cells. Four weeks later, a single dose of radiation to detectable disease was followed by a second T-cell infusion. Both infusions were followed by low-dose IL-2 administered systemically. Treatment was well tolerated. Four weeks after the first infusion, lesions were noted to regress, and eight weeks after the second infusion, all lesions had regressed by an average of $62 \%$ with complete disappearance of the metastatic lesion injected with IFN- $\beta$. Infused T cells were observed to persist for at least 6 weeks and to maintain function, as assessed by secretion of IFN- $\gamma$, TNF- $\alpha$ and IL- 2 in response to T antigen. The contribution of the cells infused to the antitumor effects is difficult to determine, as IFN- $\beta$, IL-2, and radiation were also administered. Nonetheless, the results do support further study, and extension of this approach to other patients with MCC using a broader array of MHC-restricted MCPyV epitopes is planned [102].

\subsection{Topical}

Topical immune modulators have been applied to treat a variety of skin cancers. Contact sensitizers such as dinitrochlorbenzol form stable conjugates with proteins in the epidermis and elicit cytokine production by skin cells. Sensitization has been shown to occur within the regional lymph nodes, where specific T cells come into contact with the bound dinitrochlorbenzol. A patient with multiple local and regional MCC metastases was reported to respond with complete regression to four weekly 
treatments of topically applied dinitrochlorbenzol [103]. A biopsy of a regressing lesion showed few remaining cytokeratin-20-positive tumor cell complexes in the mid to lower dermis surrounded by a dense infiltration consisting of $\mathrm{T}$ cells and macrophages. Imiquimod is a synthetic molecule that activates Toll-like receptors 7 and 8 , the natural ligand of which is pathogen-derived, single-stranded RNA. Both innate and adaptive immune systems are activated by application of imiquimod. A case report suggests the possible effective use of imiquimod, combined with radiation therapy, for MCC [104,105].

\subsection{Vaccines}

Therapeutic vaccines have been an attractive approach to many refractory malignancies. Preclinical studies have supported their use in MCC. A DNA vaccine encoding the truncated LT-Ag was able to produce antitumor effects against LT-Ag-expressing tumor cells in a mouse model. Efficacy was found to be predominantly a result of $\mathrm{CD} 4^{+} \mathrm{T}$ cells, although NK cells and $\mathrm{CD} 8^{+} \mathrm{T}$ cells did contribute to the therapeutic effects [106]. Linking a damage-associated molecular protein, calreticulin, to the LT-Ag in a DNA vaccine construct enhanced the generation of therapeutic $\mathrm{CD} 8^{+} \mathrm{T}$ cells [107]. Merkel cells and the majority of MCC express Ep-CAM, gangliosides, and MUC 1, which represent tumor-associated antigens currently being targeted via vaccine production and/or monoclonal antibody treatment strategies in other cancers [108-112]. Whether these will translate into effective treatment strategies for MCC remains to be determined.

\section{Conclusions and Future Directions}

Despite an increase in clinical and experimental data, how the immune response influences MCC development and progression remains poorly understood. It is highly likely that the immune system plays a central role in preventing and controlling $\mathrm{MCC}$, as patients who are immunosuppressed for various reasons have an increased risk. There is evidence that high intratumoral T-cell counts and immune transcripts are associated with favorable survival. Spontaneous regressions also implicate immune effector mechanisms in MCC control. Immunogenicity is also supported by observation of autoimmune paraneoplastic syndromes. Case reports suggest that immune modulation, including reduction of immune suppression, can result in $\mathrm{MCC}$ regression.

The relationships between MCPyV infection, the immune response, and MCC outcome also remain poorly understood. Circulating serum antibodies against MCPyV $\mathrm{T}$ antigen and capsid proteins are present in most individuals. MCPyV-reactive T-cells can be detected in the blood of both MCC patients and control subjects. These observations suggest that MCC often develops despite the presence of a humoral and cellular immune response against MCPyV. In the future, MCPyV-targeted immunotherapies may be developed. A better understanding on how MCPyV evades the immune response will be necessary, however, to develop effective treatments. Recent studies have focused on the production of microRNA by MCPyV that can mediate immune invasion [113]. Methods are being developed to modulate microRNA clinically [114]. It is not clear that a preventive vaccine targeting MCPyV will be clinically useful, as are preventive vaccines targeting the HPV and hepatitis oncoviruses. The link of MCC to MCPyV will need to be more convincingly established, as will the prevalence of morbidity from associated cancer and/or potentially other diseases. 
Not all MCC tumors have been associated with MCPyV. Although the numbers of intratumoral $\mathrm{T}$ cells are generally higher in MCPyV-positive than in MCPyV-negative MCC, high intratumoral T-cell counts are also associated with favorable survival in MCPyV-negative MCC, suggesting that responses to non-MCPyV, tumor-associated antigens are operational. The identity of these antigens, however, is not currently known. Further characterization of tumor and TILs could lead to identification of these antigens and novel MCC targeted immunotherapies.

Improved understanding of the mechanisms by which T-cell activation is regulated has led to the identification of "checkpoint" molecules that inhibit T-cell reactivity. Ipilimumab, an antibody that blocks cytotoxic T-lymphocyte antigen-4 (CTLA-4), an inhibitory molecule present on activated T cells, is used to treat patients with metastatic melanoma [115]. In a phase II trial in patients with small-cell lung cancer, there was evidence that ipilimumab improved progression-free survival [116]. Programmed death (PD)-1 is another immune inhibitory molecule, and initial clinical testing of a blocking antibody to the PD-1 receptor and to the PD-1 ligand has shown encouraging results [117,118]. Immune stimulatory molecules, such as $41-\mathrm{BB}, \mathrm{CD} 40$, and OX-40, are also targets, and early-phase clinical trials of activating antibodies to these have shown that they can mediate tumor regression [119]. The clinical activity of checkpoint modifiers in MCC has not, to date, been reported. Clinical trials are likely to be conducted, but more data on what checkpoints are operational in MCC are needed.

The observations supporting a role for host immunity in the incidence and course of MCC suggest that immune modulating therapies could be highly effective in treating MCC. To date, however, there are only a few reports on the activity of immunotherapies in MCC. MCC is often approached therapeutically with approaches developed for the far more common skin cancer, melanoma, and for the far more common neuroendocrine carcinoma, small-cell lung. Given the emerging role of MCPyV in MCC, these extrapolations are tenuous. The incidence of MCC has been increasing [1]. The stage is now set for more specific approaches.

\section{References}

1. Rockville Merkel Cell Carcinoma Group. Merkel cell carcinoma: Recent progress and current priorities on etiology, pathogenesis, and clinical management. J. Clin. Oncol. 2009, 27, 4021-4026.

2. Feng, H.; Shuda, M.; Chang, Y.; Moore, P.S. Clonal integration of a polyomavirus in human merkel cell carcinoma. Science 2008, 319, 1096-1100.

3. Medina-Franco, H.; Urist, M.M.; Fiveash, J.; Heslin, M.J.; Bland, K.I.; Beenken, S.W. Multimodality treatment of Merkel cell carcinoma: Case series and literature review of 1024 cases. Ann. Surg. Oncol. 2001, 8, 204-208.

4. Voog, E.; Biron, P.; Martin, J.P.; Blay, J.Y. Chemotherapy for patients with locally advanced or metastatic Merkel cell carcinoma. Cancer 1999, 85, 2589-2595.

5. Tai, P. Merkel cell cancer: Update on biology and treatment. Curr. Opin. Oncol. 2008, 20, 196-200.

6. Garneski, K.M.; Nghiem, P. Merkel cell carcinoma adjuvant therapy: Current data support radiation but not chemotherapy. J. Am. Acad. Dermatol. 2007, 57, 166-169.

7. Poulsen, M.G.; Rischin, D.; Porter, I.; Walpole, E.; Harvey, J.; Hamilton, C.; Keller, J.; Tripcony, L. Does chemotherapy improve survival in high-risk stage I and II Merkel cell carcinoma of the skin? Int. J. Radiat. Oncol. Biol. Phys. 2006, 64, 114-119. 
8. Foulongne, V.; Kluger, N.; Dereure, O.; Mercier, G.; Molès, J.P.; Guillot, B.; Segondy, M. Merkel cell polyomavirus in cutaneous swabs. Emerging Infect. Dis. 2010, 16, 685-687.

9. Foulongne, V.; Dereure, O.; Kluger, N.; Molès, J.P.; Guillot, B.; Segondy, M. Merkel cell polyomavirus DNA detection in lesional and nonlesional skin from patients with Merkel cell carcinoma or other skin diseases. Br. J. Dermatol. 2010, 162, 59-63.

10. Houben, R.; Shuda, M.; Weinkam, R.; Schrama, D.; Feng, H.; Chang, Y.; Moore, P.S.; Becker, J.C. Merkel cell polyomavirus infected Merkel cell carcinoma cells require expression of viral T antigens. J. Virol. 2010, 84, 7064-7072.

11. Shuda, M.; Kwun, H.J.; Feng, H.; Chang, Y.; Moore, P.S. Human Merkel cell polyomavirus small $\mathrm{T}$ antigen is an oncoprotein targeting the 4E-BP1 translation regulator. J. Clin. Invest. 2011, 9, 3623-3634.

12. Pastrana, D.V.; Tolstov, Y.L.; Becker, J.C.; Moore, P.S.; Chang, Y.; Buck, C.B. Quantitation of human seroresponsiveness to Merkel cell polyomavirus. PLoS Pathog. 2009, 5, e1000578.

13. Sihto, H.; Kukko, H.; Koljonen, V.; Sankila, R.; Böhling, T.; Joensuu, H. Merkel cell polyomavirus infection, large $\mathrm{T}$ antigen, retinoblastoma protein and outcome in Merkel cell carcinoma. Clin. Cancer Res. 2011, 17, 4806-4813.

14. Heath, M.; Jaimes, N.; Lemos, B.; Mostaghimi, A.; Wang, LC.; Peñas, PF.; Nghiem, P. Clinical characteristics of Merkel cell carcinoma at diagnosis in 195 patients: The AEIOU features. J. Am. Acad. Dermatol. 2008, 58, 375-381.

15. Buell, J.F.; Trofe, J.; Hanaway, M.J.; Beebe, T.M.; Gross, T.G.; Alloway, R.R.; First, M.R.; Woodle, E.S. Immunosuppression and Merkel cell cancer. Transplant. Proc. 2002, 34, 1780-1781.

16. Penn, I.; First, M.R. Merkel's cell carcinoma in organ recipients: Report of 41 cases. Transplantation 1999, 68, 1717-1721.

17. Koljonen, V.; Kukko, H.; Tukiainen, E.; Böhling, T.; Sankila, R.; Pukkala, E.; Sihto, H.; Joensuu, H.; Kyllönen, L.; Mäkisalo, H. Incidence of Merkel cell carcinoma in renal transplant recipients. Nephrol. Dial. Transplant. 2009, 24, 3231-3235.

18. Tadmor, T.; Aviv, A.; Polliack, A. Merkel cell carcinoma, chronic lymphocytic leukemia and other lymphoproliferative disorders: An old bond with possible new viral ties. Ann. Oncol. 2011, 22, 250-256.

19. Brewer, J.D.; Shanafelt, T.D.; Otley, C.C.; Roenigk, R.K.; Cerhan, J.R.; Kay, N.E.; Weaver, A.L.; Call, T.G. Chronic lymphocytic leukemia is associated with decreased survival of patients with malignant melanoma and Merkel cell carcinoma in a SEER population-based study. J. Clin. Oncol. 2012, 30, 843-849.

20. Shuda, M.; Arora, R.; Kwun, H.J.; Feng, H.; Sarid, R.; Fernández-Figueras, M.T.; Tolstov, Y.; Gjoerup, O.; Mansukhani, M.M.; Swerdlow, S.H.; et al. Human Merkel cell polyomavirus infection I. MCV T antigen expression in Merkel cell carcinoma, lymphoid tissues and lymphoid tumors. Int. J. Cancer 2009, 125, 1243-1249.

21. Cimino, P.J., Jr.; Bahler, D.W.; Duncavage, E.J. Detection of Merkel cell polyomavirus in chronic lymphocytic leukemia T-cells. Exp. Mol. Pathol. 2013, 94, 40-44.

22. Hemminki, K.; Liu, X.; Ji, J.; Sundquist, J.; Sundquist, K. Kaposi sarcoma and Merkel cell carcinoma after autoimmune disease. Int. J. Cancer 2012, 131, E326-E328. 
23. Engels, E.A.; Frisch, M.; Goedert, J.J.; Biggar, R.J.; Miller, R.W. Merkel cell carcinoma and HIV infection. Lancet 2001, 359, 497-498.

24. Tuthill, R.J.; Unger, J.M.; Liu, P.Y.; Flaherty, L.E.; Sondak, V.K.; Southwest Oncology Group. Risk assessment in localized primary cutaneous melanoma: A Southwest Oncology Group study evaluating nine factors and a test of the Clark logistic regression prediction model. Am. J. Clin. Pathol. 2002, 118, 504-511.

25. Al-Shibli, K.I.; Donnem, T.; Al-Saad, S.; Persson, M.; Bremnes, R.M.; Busund, L.T. Prognostic effect of epithelial and stromal lymphocyte infiltration in non-small cell lung cancer. Clin. Cancer Res. 2008, 14, 5220-5227.

26. Zhang, L.; Conejo-Garcia, J.R.; Katsaros, D.; Gimotty, P.A.; Massobrio, M.; Regnani, G.; Makrigiannakis, A.; Gray, H.; Schlienger, K.; Liebman, M.N.; Rubin, S.C.; Coukos, G. Intratumoral T cells, recurrence, and survival in epithelial ovarian cancer. N. Engl. J. Med. 2003, 348, 203-213.

27. Andea, A.A.; Coit, D.G.; Amin, B.; Busam, K.J. Merkel cell carcinoma: Histologic features and prognosis. Cancer 2008, 113, 2549-2558.

28. Llombart, B.; Monteagudo, C.; Lopez-Guerrero, J.A.; Carda, C.; Jorda, E.; Sanmartin, O.; Almenar, S.; Molina, I.; Martin, J.M.; Llombart-Bosch, A. Clinicopathological and immunohistochemical analysis of 20 cases of Merkel cell carcinoma in search of prognostic markers. Histopathology 2005, 46, 622-634.

29. Sihto, H.; Böhling, T.; Kavola, H.; Koljonen, V.; Salmi, M.; Jalkanen, S.; Joensuu, H. Tumor infiltrating immune cells and outcome of Merkel cell carcinoma: A population-based study. Clin. Cancer Res. 2012, 18, 2872-2881.

30. Paulson, K.G.; Iyer, J.G.; Tegeder, A.R.; Thibodeau, R.; Schelter, J.; Koba, S.; Schrama, D.; Simonson, W.T.; Lemos, B.D.; Byrd, D.R.; et al. Transcriptome-wide studies of Merkel cell carcinoma and validation of intratumoral CD8+ lymphocyte invasion as an independent predictor of survival. J. Clin. Oncol. 2011, 12, 1539-1546.

31. Zhang, L.; Conejo-Garcia, J.R.; Katsaros, D.; Gimotty, P.A.; Massobrio, M.; Regnani, G.; Makrigiannakis, A.; Gray, H.; Schlienger, K.; Liebman, M.N.; et al. Intratumoral T cells, recurrence, and survival in epithelial ovarian cancer. N. Engl. J. Med. 2003, 348, 203-213.

32. Galon, J.; Costes, A.; Sanchez-Cabo, F.; Kirilovsky, A.; Mlecnik, B.; Lagorce-Pagès, C.; Tosolini, M.; Camus, M.; Berger, A.; Wind, P.; et al. Type, density, and location of immune cells within human colorectal tumors predict clinical outcome. Science 2006, 313, 1960-1964.

33. Mott, R.T.; Smoller, B.R.; Morgan, M.B. Merkel cell carcinoma: A clinicopathologic study with prognostic implications. J. Cutan. Pathol. 2004, 31, 217-223.

34. Wang, W.; Hodkinson, P.; McLaren, F.; MacKinnon, A.; Wallace, W.; Howie, S.; Sethi, T. Small cell lung cancer tumour cells induce regulatory $\mathrm{T}$ lymphocytes, and patient survival correlates negatively with FOXP3+ cells in tumour infiltrate. Int. J. Cancer 2012, 131, E928-E937.

35. Gooden, M.J.M.; de Bock, G.H.; Leffers, N.; Daemen, T.; Nijman, H.W. The prognostic influence of tumor-infiltrating lymphocytes in cancer: A systematic review with meta-analysis. Br. J. Cancer 2011, 105, 93-103. 
36. Jensen, T.O.; Schmidt, H.; Møller, H.J.; Høyer, M.; Maniecki, M.B.; Sjoegren, P.; Christensen, I.J.; Steiniche, T. Macrophage markers in serum and tumor have prognostic impact in American Joint Committee on Cancer stage I/II melanoma. J. Clin. Oncol. 2009, 27, 3330-3337.

37. Montero, A.J.; Diaz-Montero, C.M.; Kyriakopoulos, C.E.; Bronte, V.; Mandruzzato, S. Myeloid-derived suppressor cells in cancer patients: A clinical perspective. J. Immunother. 2012, $35,107-115$.

38. Zitvogel, L.; Kepp, O.; Aymeric, L.; Ma, Y.; Locher, C.; Delahaye, N.F.; André, F.; Kroemer, G. Integration of host-related signatures with cancer cell-derived predictors for the optimal management of anticancer chemotherapy. Cancer Res. 2010, 70, 9538-9543.

39. Arany, I.; Tyring, S.K. Status of cytokine and antigen presentation genes in Merkel cell carcinoma of the skin. J. Cutan. Med. Surg. 1998, 2, 138-141.

40. Connelly, T. Regarding complete spontaneous regression of Merkel cell carcinoma. Dermatol. Surg. 2009, 35, 721.

41. Allen, P.J.; Bowne, W.B.; Jaques, D.P.; Brennan, M.F.; Busam, K.; Coit, D.G. Merkel cell carcinoma: Prognosis and treatment from a single institution. J. Clinl. Oncol. 2005, 23, 2300-2309.

42. Hui, A.; Stillie, A.; Seel, M.; Ainslie, J. Merkel cell carcinoma: 27 Year experience at the Peter MacCallum Cancer Centre. Int. J. Radiat. Oncol. Biol. Phys. 2011, 80, 1430-1435.

43. Foote, M.; Veness, M.; Zarate, D.; Poulsen, M. Merkel cell carcinoma: The prognostic implications of an occult primary in stage IIIB (nodal) disease. J. Am. Acad. Dermatol. 2012, 67, 395-399.

44. Deneve, J.L.; Messina, J.L.; Marzban, S.S.; Gonzalez, R.J.; Walls, B.M.; Fisher, K.J.; Chen, Y.A.; Cruse, C.W.; Sondak, V.K.; Zager, J.S. Merkel cell carcinoma of unknown primary origin. Ann. Surg. Oncol. 2012, 19, 2360-2366.

45. Wooff, J.C.; Trites, J.R.; Walsh, N.M.; Bullock, M.J. Complete spontaneous regression of metastatic merkel cell carcinoma: A case report and review of the literature. Am. J. Dermatopathol. 2010, 32, 614-617.

46. Cotter, S.E.; Dunn, G.P.; Collins, K.M.; Sahni, D.; Zukotynski, K.A.; Hansen, J.L.; O’Farrell, D.A.; Ng, A.K.; Devlin, P.M.; Wang, L.C. Abscopal effect in a patient with metastatic Merkel cell carcinoma following radiation therapy: Potential role of induced antitumor immunity. Arch. Dermatol. 2011, 147, 870-872.

47. Kayashima, K.; Ono, T.; Johno, M.; Kojo, Y.; Yamashita, N.; Matsunaga, W. Spontaneous regression in Merkel cell (neuroendocrine) carcinoma of the skin. Arch. Dermatol. 1991, 127, 550-553.

48. Maruo, K.; Kayashima, K.I.; Ono, T. Regressing Merkel cel carcinoma-a case showing replacement of tumour cells by foamy cells. Br. J. Dermatol. 2000, 142, 1184-1189.

49. Vesely, M.J.; Murray, DJ.; Neligan, P.C.; Novak, C.B.; Gullane, P.J.; Ghazarian, D. Complete spontaneous regression in Merkel cell carcinoma. J. Plast. Reconstr. Aesthet. Surg. 2008, 61, 165-171.

50. Inoue, T.; Yoneda, K.; Manabe, M.; Demitsu, T. Spontaneous regression of merkel cell carcinoma: A comparative study of TUNEL index and tumor-infiltrating lymphocytes between spontaneous regression and non-regression group. J. Dermatol. Sci. 2000, 24, 203-211. 
51. Koba, S.; Paulson, K.G.; Nagase, K.; Tegeder, A.; Thibodeau, R.; Iyer, J.G.; Narisawa, Y.; Nghiem, P. Diagnostic biopsy does not commonly induce intratumoral CD8 T cell infiltration in merkel cell carcinoma. PLoS One 2012, 7, e41465.

52. Richetta, A.G.; Mancini, M.; Torroni, A.; Lorè, B.; Iannetti, G.; Sardella, B.; Calvieri, S. Total spontaneous regression of advanced merkel cell carcinoma after biopsy: Review and a new case. Dermatol. Surg. 2008, 34, 815-822.

53. Junquera, L.; Torre, A.; Vicente, J.C.; García-Consuegra, L.; Fresno, M.F. Complete spontaneous regression of Merkel cell carcinoma. Ann. Otol. Rhinol. Laryngol. 2005, 114, 376-380.

54. Chiu, L.S.; Choi, P.C.; Luk, N.M.; Chang, M.; Tang, W.Y. Spontaneous regression of primary cutaneous Epstein-Barr virus-positive, CD30-positive anaplastic large T-cell lymphoma in a heart-transplant recipient. Clin. Exp. Dermatol. 2009, 34, e21-e24.

55. Adiguzel, C.; Bozkurt, S.U.; Kaygusuz, I.; Uzay, A.; Tecimer, T.; Bayik, M. Human herpes virus 8-unrelated primary effusion lymphoma-like lymphoma: Report of a rare case and review of the literature. APMIS 2009, 117, 222-229.

56. Abe, R.; Ogawa, K.; Maruyama, Y.; Nakamura, N.; Abe, M. Spontaneous regresión of diffuse large B-cell lymphoma harbouring Epstein-Barr virus: A case report and review of the literature. J. Clin. Exp. Hematop. 2007, 47, 23-26.

57. Yagi, Y.; Fujisawa, A.; Makiura, M.; Morita, K. Spontaneous regression of Merkel cell carcinoma after biopsy. J. Dermatol. 2009, 36, 312-313.

58. Maddison, P.; Lang, B. Paraneoplastic neurological autoimmunity and survival in small-cell lung cancer. J. Neuroimmunol. 2008, 201-202, 159-162.

59. Balegno, S.; Ceroni, M.; Corato, M.; Franciotta, D.; Giometto, B.; Marinu-Aktipu, K.; Nano, R. Antibodies to cerebellar nerve fibres in two patients with paraneoplastic cerebellar ataxia. Anticancer Res. 2005, 25, 3211-3214.

60. Lopez, M.C.; Pericay, C.; Agustí, M.; Martinez-Gallo, M.; Bordes, R.; Gelpí, C. Merkel cell carcinoma associated with a paraneoplastic neurological syndrome. Histopathology 2004, 44, 628-629.

61. Greenlee, J.E.; Steffens, J.D.; Clawson, S.A.; Hill, K.; Dalmau, J. Anti-Hu antibodies in Merkel cell carcinoma. Ann. Neurol. 2002, 52, 111-115.

62. Cher, L.M.; Hochberg, F.H.; Teruya, J.; Nitschke, M.; Valenzuela, R.F.; Schmahmann, J.D.; Herbert, M.; Rosas, H.D.; Stowell, C. Therapy for paraneoplastic neurologic syndromes in six patients with protein A column immunoadsorption. Cancer 1995, 75, 1678-1683.

63. Eggers, S.D.; Salomao, D.R.; Dinapoli, R.P.; Vernino, S. Paraneoplastic and metastatic neurologic complications of Merkel cell carcinoma. Mayo Clin. Proc. 2001, 76, 327-330.

64. Muirhead, R.; Ritchie, D.M. Partial regression of Merkel cell carcinoma in response to withdrawal of azathioprine in an immunosuppression-induced case of metastatic Merkel cell carcinoma. Clin. Oncol. (R. Coll. Radiol.) 2007, 19, 96.

65. Friedlaender, M.M.; Rubinger, D.; Rosenbaum, E.; Amir, G.; Siguencia, E. Temporary regression of Merkel cell carcinoma metastases after cessation of cyclosporine. Transplantation 2002, 73, 1849-1850. 
66. Kauffman, H.M.; Cherikh, W.S.; Cheng, Y.; Hanto, D.W.; Kahan, B.D. Maintenance immunosuppression with target-of-rapamycin inhibitors is associated with a reduced incidence of de novo malignancies. Transplantation 2005, 80, 883-889.

67. Tolstov, Y.L.; Pastrana, D.V.; Feng, H.; Becker, J.C.; Jenkins, F.J.; Moschos, S.; Chang, Y.; Buck, C.B.; Moore, P.S. Human Merkel cell polyomavirus infection II. MCV is a common human infection that can be detected by conformational capsid epitope immunoassays. Int. J. Cancer 2009, 125, 1250-1256.

68. Chen, T.; Hedman, L.; Mattila, P.S.; Jartti, T.; Ruuskanen, O.; Söderlund-Venermo, M.; Hedman, K. Serological evidence of Merkel cell polyomavirus primary infections in childhood. J. Clin. Virol. 2010, 50, 125-129.

69. Kean, J.M.; Rao, S.; Wang, M.; Garcea, R.L. Seroepidemiology of human polyomaviruses. PLoS Pathog. 2009, 5, e1000363.

70. Carter, J.J.; Paulson, K.G.; Wipf, G.C.; Miranda, D.; Madeleine, M.M.; Johnson, L.G.; Lemos, B.D.; Lee, S.; Warcola, A.H.; Iyer, J.G.; et al. Association of Merkel cell polyomavirus-specific antibodies with Merkel cell carcinoma. J. Natl. Cancer Inst. 2009, 101, 1510-1522.

71. Paulson, K.G.; Carter, J.J.; Johnson, L.G.; Cahill, K.W.; Iyer, J.G.; Schrama, D.; Becker, J.C.; Madeleine, M.M.; Nghiem, P.; Galloway, D.A. Antibodies to Merkel cell polyomavirus T-antigen oncoproteins reflect tumor burden in Merkel cell carcinoma patients. Cancer Res. 2010, 70, 8388-8397.

72. Besson, C.; Amiel, C.; Le-Pendeven, C.; Brice, P.; Ferme, C.; Carde, P.; Hermine, O.; Raphael, M.; Abel, L.; Nicolas, J.C. Positive correlation between Epstein-Barr virus viral load and anti-viral capsid immunoglobulin $\mathrm{G}$ titers determined for Hodgkin's lymphoma patients and their relatives. J. Clin. Microbiol. 2006, 44, 47-50.

73. Morand-Joubert, L.; Mariotti, M.; Reed, D.; Petit, J.C.; Lefrere, J.J. Correlation between viral DNA load and serum anti p19 antibody concentration in symptomless human T-lymphotropic virus type-I (HTLV-I)-infected individuals. Int. J. Cancer 1995, 60, 156-159.

74. Hung, I.F.; To, K.K.; Lee, C.K.; Lin, C.K.; Chan, J.F.; Tse, H.; Cheng, V.C.; Chen, H.; Ho, P.L.; Tse, C.W.; et al. Effect of clinical and virological parameters on the level of neutralizing antibody against pandemic influenza A virus H1N1 2009. Clin. Infect. Dis. 2010, 51, 274-279.

75. Randhawa, P.; Bohl, D.; Brennan, D.; Ruppert, K.; Ramaswami, B.; Storch, G.; March, J.; Shapiro, R.; Viscidi, R. longitudinal analysis of levels of immunoglobulins against BK virus capsid proteins in kidney transplant recipients. Clin. Vaccine Immunol. 2008, 15, 1564-1571.

76. Lundstig, A.; Stattin, P.; Persson, K.; Sasnauskas, K.; Viscidi, R.P.; Gislefoss, R.E.; Dillner, J. No excess risk for colorectal cancer among subjects seropositive for the JC polyomavirus. Int. J. Cancer 2007, 121, 1098-1102.

77. Faust, H.; Pastrana, D.V.; Buck, C.B.; Dillner, J.; Ekström, J. Antibodies to Merkel cell polyomavirus correlate to presence of viral DNA in the skin. J. Infect. Dis. 2011, 203, 1096-1100.

78. Pastrana, D.V.; Wieland, U.; Silling, S.; Buck, C.B.; Pfister, H. Positive correlation between Merkel cell polyomavirus viral load and capsid-specific antibody titer. Med. Microbiol. Immunol. 2012, 201, 17-23. 
79. Nakamura, T.; Sato, Y.; Watanabe, D.; Ito, H.; Shimonohara, N.; Tsuji, T.; Nakajima, N.; Suzuki, Y.; Matsuo, K.; Nakagawa, H.; et al. Nuclear localization of Merkel cell polyomavirus large T-antigen in Merkel cell carcinoma. Virology 2010, 398, 273-279.

80. Touzé, A.; Le Bidre, E.; Laude, H.; Fleury, M.J.; Cazal, R.; Arnold, F.; Carlotti, A.; Maubec, E.; Aubin, F.; Avril, M.F.; et al. High levels of antibodies against merkel cell polyomavirus identify a subset of patients with merkel cell carcinoma with better clinical outcome. J. Clin. Oncol. 2011, 29, 1612-1619.

81. Winter, S.F.; Sekido, Y.; Minna, J.D.; McIntire, D.; Johnson, B.E.; Gazdar, A.F.; Carbone, D.P. Antibodies against autologous tumor cell proteins in patients with small-cell lung cancer: Association with improved survival. J. Natl. Cancer Inst. 1993, 85, 2012-2018.

82. Gheuens, S.; Bord, E.; Kesari, S.; Simpson, D.M.; Gandhi, R.T.; Clifford, D.B.; Berger, J.R.; Ngo, L.; Koralnik, I.J. Role of CD4+ and CD8+ T-cell responses against JC virus in the outcome of patients with progressive multifocal leukoencephalopathy (PML) and PML with immune reconstitution inflammatory syndrome. J. Virol. 2011, 85, 7256-7263.

83. Schneidawind, D.; Schmitt, A.; Wiesneth, M.; Mertens, T.; Bunjes, D.; Freund, M.; Schmitt, M. Polyomavirus BK-specific CD8 $+\mathrm{T}$ cell responses in patients after allogeneic stem cell transplant. Leuk. Lymphoma 2010, 51, 1055-1062.

84. Chan, P.K.; Liu, S.J.; Cheung, J.L.; Cheung, T.H.; Yeo, W.; Chong, P.; Man, S. T-cell response to human papillomavirus type $52 \mathrm{L1}$, E6, and E7 peptides in women with transient infection, cervical intraepithelial neoplasia, and invasive cancer. J. Med. Virol. 2011, 83, 1023-1030.

85. Rehermann, B.; Nascimbeni, M. Immunology of hepatitis B virus and hepatitis C virus infection. Nat. Rev. Immunol. 2005, 5, 215-229.

86. Kumar, A.; Chen, T.; Pakkanen, S.; Kantele, A.; Söderlund-Venermo, M.; Hedman, K.; Franssila, R. T-helper cell-mediated proliferation and cytokine responses against recombinant Merkel cell polyomavirus-like particles. PLoS One 2011, 6, e25751.

87. Iyer, J.G.; Afanasiev, O.K.; McClurkan, C.; Paulson, K.; Nagase, K.; Jing, L.; Marshak, J.O.; Dong, L.; Carter, J.; Lai, I.; et al. Merkel cell polyomavirus-specific CD8+ and CD4+ T-cell responses identified in Merkel cell carcinomas and blood. Clin. Cancer Res. 2011, 17, 6671-6680.

88. Mishra, R.; Chen, A.T.; Welsh, R.M.; Szmolanyi-Tsuda, E. NK cells and gammadelta T cells mediate resistance to polyomavirus-induced tumors. PLoS Pathog. 2010, 6, e1000924.

89. Co, J.K.; Verma, S.; Gurjav, U.; Sumibcay, L.; Nerurkar, V.R. Interferon-alpha and -beta restrict polyomavirus JC replication in primary human fetal glial cells: Implications for progressive multifocal leukoencephalopathy therapy. J. Infect. Dis. 2007, 96, 2-8.

90. Abend, J.R.; Low, J.A.; Imperiale, M.J. Inhibitory effect of gamma interferon on BK virus gene expression and replication. J. Virol. 2007, 81, 272-279.

91. Krasagakis, K.; Kruger-Krasagakis, S.; Tzanakakis, G.N.; Darivianaki, K.; Stathopoulos, E.N.; Tosca, A.D. Interferon-alpha inhibits proliferation and induces apoptosis of merkel cell carcinoma in vitro. Cancer Invest. 2008, 26, 562-568.

92. Willmes, C.; Adam, C.; Alb, M.; Völkert, L.; Houben, R.; Becker, J.C.; Schrama, D. Type I and II IFNs inhibit Merkel cell carcinoma via modulation of the Merkel cell polyomavirus $\mathrm{T}$ antigens. Cancer Res. 2012, 72, 2120-2128. 
93. Durand, J.M.; Weiller, C.; Richard, M.A.; Portal, I.; Mongin, M. Treatment of Merkel cell tumor with interferon-alpha-2b. Br. J. Dermatol. 1991, 124, 509.

94. Nakajima, H.; Takaishi, M.; Yamamoto, M.; Kamijima, R.; Kodama, H.; Tarutani, M.; Sano, S. Screening of the specific polyoma virus as diagnostic and prognostic tools for Merkel cell carcinoma. J. Dermatol. Sci. 2009, 56, 211-213.

95. Bajetta, E.; Zilembo, N.; di Bartolomeo, M.; di Leo, A.; Pilotti, S.; Bochicchio, A.M.; Castellani, R.; Buzzoni, R.; Celio, L.; Dogliotti, L.; et al. Treatment of metastatic carcinoids and other neuroendocrine tumors with recombinant interferon-alpha-2a. A study by the Italian Trials in Medical Oncology Group. Cancer 1993, 72, 3099-3105.

96. Biver-Dalle, C.; Nguyen, T.; Touzé, A.; Saccomani, C.; Penz, S.; Cunat-Peultier, S.; Riou-Gotta, M.O.; Humbert, P.; Coursaget, P.; Aubin, F. Use of interferon-alpha in two patients with Merkel cell carcinoma positive for Merkel cell polyomavirus. Acta Oncol. 2011, 50, 479-480.

97. Matsushita, E.; Hayashi, N.; Fukushima, A.; Ueno, H. Evaluation of treatment and prognosis of Merkel cell carcinoma of the eyelid in Japan. Nippon Ganka Gakkai Zasshi 2007, 111, 459-462.

98. Hata, Y.; Matsuka, K.; Ito, O.; Matsuda, H.; Furuichi, H.; Konstantinos, A.; Nuri, B. Two cases of Merkel cell carcinoma cured by intratumor injection of natural human tumor necrosis factor. Plast. Reconstr. Surg. 1997, 99, 547-553.

99. Olieman, A.F.; Liénard, D.; Eggermont, A.M.; Kroon, B.B.; Lejeune, F.J.; Hoekstra, H.J.; Koops, H.S. Hyperthermic isolated limb perfusion with tumor necrosis factor alpha, interferon gamma, and melphalan for locally advanced nonmelanoma skin tumors of the extremities: A multicenter study. Arch. Surg. 1999, 134, 303-307.

100. Burack, J.; Altschuler, E.L. Sustained remission of metastatic Merkel cell carcinoma with treatment of HIV infection. J. R. Soc. Med. 2003, 96, 238-239.

101. OMS-I100_Phase II Metastatic Melanoma Clinical Trial. Available online: http://oncosec.com/ index.php/oms/clinical-trials/ (accessed on 30 January 2013).

102. Chapuis, A.G.; Afanasiev, O.; Iyer, J.; Parvathaneni, U.; Hwang, J.H.; Lai, I.; Roberts, I.; Farrar, E.; Koelle, D.; Nghiem, P.; et al. Anti-polyomavirus CTL targeting Merkel cell carcinoma combined with MHC class I upregulation induces tumor regression. Cancer Res. 2012, 72, Abstract LB-430.

103. Herrmann, G.; Groth, W.; Krieg, T.; Mauch, C. Complete remission of Merkel cell carcinoma of the scalp with local and regional metastases after topical treatment with dinitrochlorbenzol. J. Am. Acad. Dermatol. 2004, 50, 965-969.

104. Scott, D.R. Apparent response of cutaneous Merkel cell tumor to topical imiquimod. Cutis 2006, 77, 109-110.

105. Balducci, M.; de Bari, B.; Manfrida, S.; D’Agostino, G.R.; Valentini, V. Treatment of Merkel cell carcinoma with radiotherapy and imiquimod (Aldara): A case report. Tumori 2010, 96, 508-511.

106. Zeng, Q.; Gomez, B.P.; Viscidi, R.P.; Peng, S.; He, L.; Ma, B.; Wu, T.C.; Hung, C.F. Development of a DNA vaccine targeting Merkel cell polyomavirus. Vaccine 2012, 30, 1322-1329.

107. Gomez, B.P.; Wang, C.J.; Viscidi, R.P.; Peng, S.; He, L.; Wu, T.C.; Hung, C.F. Strategy for eliciting antigen-specific CD8 $+\mathrm{T}$ cell-mediated immune response against a cryptic CTL epitope of merkel cell polyomavirus large T antigen. Cell Biosci. 2012, 2, 36. 
108. Kurzen, H.; Kaul, S.; Egner, U.; Deichmann, M.; Hartschuh, W. Expression of MUC 1 and Ep-CAM in Merkel cell carcinomas: Implications for immunotherapy. Arch. Dermatol. Res. 2003, 295, 146-154.

109. Erickson, K.D.; Garcea, R.L.; Tsai, B. Ganglioside GT1b is a putative host cell receptor for the Merkel cell polyomavirus. J. Virol. 2009, 83, 10275-10279.

110. Beatson, R.E.; Taylor-Papadimitriou, J.; Burchell, J.M. MUC1 immunotherapy. Immunotherapy 2010, 2, 305-327.

111. Sithambaram, D.; Palanivelu, S.; Subramanian, K.; Sahoo, S.; Verma, R.S. Specific targeting of Ep-CAM in various carcinomas by novel monoclonal antibodies. Hybridoma (Larchmt.) 2011, 30, 511-518.

112. Giaccone, G.; Debruyne, C.; Felip, E.; Chapman, P.B.; Grant, S.C.; Millward, M.; Thiberville, L.; D'addario, G.; Coens, C.; Rome, L.S.; et al. Phase III study of adjuvant vaccination with Bec2/Bacille Calmette-Guerin in responding patients with limited-disease small-cell lung cancer (European Organisation for Research and Treatment of Cancer 08971-08971B; Silva study). J. Clin. Oncol. 2005, 23, 6854-6864.

113. Lee, S.; Paulson, K.G.; Murchison, E.P.; Afanasiev, O.K.; Alkan, C.; Leonard, J.H.; Byrd, D.R.; Hannon, G.J.; Nghiem, P. Identification and validation of a novel mature microRNA encoded by the Merkel cell polyomavirus in human Merkel cell carcinomas. J. Clin. Virol. 2011, 52, 272-275.

114. Jackson, A.; Linsley, P.S. The therapeutic potential of microRNA modulation. Discov. Med. 2010, 9, 311-348.

115. Hodi, F.S.; O’Day, S.J.; McDermott, D.F.; Weber, R.W.; Sosman, J.A.; Haanen, J.B.; Gonzalez, R.; Robert, C.; Schadendorf, D.; Hassel, J.C.; et al. Improved survival with ipilimumab in patients with metastatic melanoma. N. Engl. J. Med. 2010, 363, 711-723.

116. Reck, M.; Bondarenko, I.; Luft, A.; Serwatowski, P.; Barlesi, F.; Chacko, R.; Sebastian, M.; Lu, H.; Cuillerot, J.M.; Lynch, T.J. Ipilimumab in combination with paclitaxel and carboplatin as first-line therapy in extensive-disease-small-cell lung cancer: Results from a randomized, double-blind, multicenter phase 2 trial. Ann. Oncol. 2012, doi:10.1093/annonc/mds213.

117. Brahmer, J.R.; Tykodi, S.S.; Chow, L.Q.; Hwu, W.J.; Topalian, S.L.; Hwu, P.; Drake, C.G.; Camacho, L.H.; Kauh, J.; Odunsi, K.; et al. Safety and activity of anti-PD-L1 antibody in patients with advanced cancer. N. Engl. J. Med. 2012, 366, 2455-2465.

118. Topalian, S.L.; Hodi, F.S.; Brahmer, J.R.; Gettinger, S.N.; Smith, D.C.; McDermott, D.F.; Powderly, J.D.; Carvajal, R.D.; Sosman, J.A.; Atkins, M.B.; et al. Safety, activity, and immune correlates of anti-PD-1 antibody in cancer. N. Engl. J. Med. 2012, 366, 2443-2454.

119. Wolchok, J.D.; Yang, A.S.; Weber, J.S. Immune regulatory antibodies: Are they the next advance? Cancer J. 2010, 16, 311-317.

(C) 2013 by the authors; licensee MDPI, Basel, Switzerland. This article is an open access article distributed under the terms and conditions of the Creative Commons Attribution license (http://creativecommons.org/licenses/by/3.0/). 